\title{
Nutritional and Phytochemical Composition of Fruit Bioproducts
}

\author{
Josileide Gonçalves Borges (Corresponding Author) \\ Biotechnology Post graduate Program (PPGBiotec), Feira de Santana State University, Feira \\ de Santana, Bahia, Brazil; Federal University of San Francisco Valley (UNIVASF). Av José Sá \\ de Maniçoba S/N, Centro, 56304-917, Petrolina, Pernambuco, Brazil, Fone: 5508721016862 \\ E-mail: josileide.borges@univasf.edu.br \\ Jackson Roberto Guedes da Silva Almeida \\ Biotechnology Post graduate Program (PPGBiotec), Feira de Santana State University, Feira \\ de Santana, Bahia, Brazil; Federal University of San Francisco Valley (UNIVASF). Av José Sá \\ de Maniçoba S/N, Centro, 56304-917, Petrolina, Pernambuco, Brazil \\ E-mail: Jackson.guedes@ univasf.edu.br
}

João Victor Pinheiro

Federal University of San Francisco Valley (UNIVASF). Av José Sá de Maniçoba S/N, Centro, 56304-917, Petrolina, Pernambuco, Brazil. E-mail: jvrpinheiro@gmail.com

Juliana Anielle Ribeiro de Sá

Federal University of San Francisco Valley (UNIVASF). Av José Sá de Maniçoba S/N, Centro, 56304-917, Petrolina, Pernambuco, Brazil. E-mail: july_anielle@ hotmail.com

Kaline Stela Pires Bezerra

Federal University of San Francisco Valley (UNIVASF). Av José Sá de Maniçoba S/N, Centro, 56304-917, Petrolina, Pernambuco, Brazil. E-mail: stela.farma@gmail.com

\section{Ingrid Lessa Leal}

Technology College SENAI-CIMATEC, food and beverage laboratory. Av. Orlando Gomes, 1845 - Piatã, 41650-010, Salvador, Bahia, Brazil. E-mail: Ingrid.leal@fbter.org.br 


\begin{abstract}
Interest in fiber-rich foods, phytochemicals with antioxidant potential has been steadily increasing as people want to get health benefits other than basic nutrition. This study aimed to draw a profile of chemical composition, phytochemical profile of fruit pomaces grown in semi arid region of Brazil. Grapes, passion fruit, orange and pomegranate were analyzed for crude protein, lipid, moisture, mineral residue, non-fibrous carbohydrate, acid detergent fiber, neutral detergent fiber levels. Quantities of total tannins, flavonoids, anthocyanins were also quantified. All ointments have a varied nutritional profile with non-fibrous carbohydrates (67.36-28.63\%), Neutral Detergent Fiber (48.18 -18.93\%), Acid Detergent Fiber (32.28 -11.64\%). All phytochemicals were detected in all bagasse cultures. Flavonoid values varied among pomaces. Punica granatum (seed) presented highest flavonoid contents $(2123.56 \mu \mathrm{g} / 100 \mathrm{~mL})$, Passiflora edulis presented lowest values $(70.09 \mu \mathrm{g} / 100 \mathrm{~mL})$. Vitis labrusca had highest anthocyanin values $(101.24 \mu \mathrm{g} / 100 \mathrm{~mL})$, Citrus sinensis had lowest values $(1.25 \mu \mathrm{g} / 100 \mathrm{~mL})$. Punica granatum seed presented highest total tannin content $(43.73 \mu \mathrm{g} / 100 \mathrm{~mL})$ and Passiflora edulis, smallest (1.55 $\mu \mathrm{g} / 100 \mathrm{~mL})$, respectively. Presence of high content of insoluble fibers, phytochemicals with antioxidant potential in ointments shows their potential use in treatment of non-contagious diseases.
\end{abstract}

Keywords: fibers, chemical characterization, fruit pomaces, phytochemical compounds

\title{
1. Introduction
}

Fruit bioproducts has been subject of several researches due to its nutritional value, high fiber content and phytochemical potential, which makes that foods that use these pomace in addition to nourishing act as protective agents to health. Epidemiological studies suggest that consumption of fruit and vegetables can reduce risks of chronic diseases (Moo et al., 2016; Rodriguez-Casado, 2016), that insoluble dietary fibre (IDF) and soluble dietary fibre (SDF) are of benefit to human health. Although it is believed that to have much more essential physiological function and consumption of foods, beverages rich in polyphenols reduces risk of chronic no communicable diseases (CNCD) (Ling et al., 2019; Sheng et al., 2018; Zhang et al., 2018; Zhao et al., 2017).

Dietary fibers are extensively studied due to their beneficial physiological effects. Several papers about fibers have been conducted in recent times, noting its many come health benefits, both in treatment as prevention of cardiovascular diseases (Eshak et al., 2010), obesity (Papathanasopoulos; Camilleri, 2010), colon cancer (Kaczmarczyk; Miller \& Freund, 2012). In addition to reduce answer glicemica, plasma levels of cholesterol (Elleuch et al., 2011), LDL cholesterol (Solá et al., 2010), improve function of large intestine and attenuation of post-prandial glucose and insulin levels in blood (Mudgil; Barak, 2013). Fruit pomaces have 
significant amounts of fiber, protein, lipids, carbohydrates, vitamins, minerals and can be used for food enrichment and dietary supplements.

Exotic tropical fruits are known to be rich in bioactive constituents (phenolic compounds, carotenoids, vitamins, fibers) that can be found in their by-products, sometimes even in higher amounts than edible parts In recent years, many studies have sought to find new applications for these types of waste (Corrêa et al., 2016; Mirabella, Castellani \& Sala, 2014).

Many people have become aware of the likely health benefits of a high fiber diet and this has encouraged many food manufacturers to develop a variety of fiber enriched food products (Cheung, 2013; Ktenioudaki; Gallagher, 2012). High fiber content nutritional supplements can be used to prepare a variety of enriched food products without any significant change in taste and texture. Peel flours and fruit seeds are being used by the food industry to enrich the nutritional value of foods, especially to increase the amount of fiber, protein and the presence of phytochemicals. Objective of this study was to analyze nutritional, phytochemical composition of fruit pomaces grown in Brazilian semi-arid region.

\section{Material and Methods}

\subsection{Preparation of Fruit Pomaces}

Fruits Passiflora edulis f. flavicarpa, Citrus sinensis, Punica granatum were purchased from local farmers. Grape pomaces of Vitis labrusca (20\% violet, $80 \%$ precose Isabel) were kindly supplied from Cooperativa Agrícola Nova Aliança (COANA) from Petrolina city, Brazil. After extracting fruit juice, solid parts (pomaces) were dried separately in a forced air oven $\left(40{ }^{\circ} \mathrm{C}\right)$. Dried samples were ground in a coffee mill (Candence), sieved to a uniform particle size (40 mesh), stored in plastic bags.

\subsection{Nutritional Analyses}

\subsubsection{Lipids}

Moisture, mineral residue, lipid, protein content were determined following official methodology (AOAC, 1998). Lipids (L) were determined by Soxlet using chloroform: methanol (2:1) mixture and kept under heating for 4 hours. Solvent was distilled off, residue was placed in an oven at $105{ }^{\circ} \mathrm{C}$ for about one hour for solvent evaporation and subsequent weighing. After this step, lipid content was determined by equation 1:

$$
\% \mathrm{~L}=(\text { Sample weight }- \text { weight of sample defatted }) / \text { Sample weight } \times 100
$$

\subsubsection{Crude Protein}

Nitrogen $(\mathrm{N})$ was measured by kjeldahl, which consists of three steps: sample digestion, distillation and titration. First the sample was completely oxidized with strong acid (sulfuric acid) until protein nitrogen was reduced to ammonium sulfate. Ammonia released from sulfate by addition of sodium hydroxide was distilled, mixed with boric acid. Amount of base was titrated with a standard hydrochloric acid solution. Nitrogen content was multiplied by 6.25 (factor used in general foods) to convert measured nitrogen into protein. Protein quantification of the sample was determined by equation 2 : 
Crude Protein $(\mathrm{PB})=$ total nitrogen content $($ kjeldahl $) \times$ factor .

\subsubsection{Mineral Residue}

Mineral residue (RM) was determined by gravimetric method with sample incineration $(2 \mathrm{~g})$ in crucibles, previously heated in a muffle furnace at $550{ }^{\circ} \mathrm{C}$, cooled in a desiccator containing silica to room temperature, weighed in analytical balance. Samples were incinerated in a muffle furnace for 4 hours at $550{ }^{\circ} \mathrm{C}$, cooled, weighed. Amount of mineral waste was calculated using equation 3 :

$$
\frac{100 x N}{P}=\text { ashes per cent }(\mathrm{m} / \mathrm{m})
$$

Where:

$\mathrm{N}=$ amount of grams of ash

$\mathrm{P}=$ amount of sample grams

\subsubsection{Neutral Detergent Fibre}

Acid detergent fiber (ADF), neutral detergent fiber (NDF) were determined according to ANKOM Technology-4/11 methodology where 0.45 to $0.55 \mathrm{~g}$ of samples were weighed in 23 pouches, degassed for 10 minutes with acetone. $20 \mathrm{~g}$ of detergent solution, $4 \mathrm{~mL}$ of alpha amylase were added to mixture. Material was heated for 75 minutes, washed with $1900 \mathrm{~mL}$ of water $\left(50\right.$ to $\left.90{ }^{\circ} \mathrm{C}\right)+4 \mathrm{~mL}$ of alpha amylase $(3 \mathrm{x})$, excess water was removed. Pouches were immersed in acetone for 3 to 5 minutes, oven dried at $102{ }^{\circ} \mathrm{C}$ for $\pm 2 \mathrm{~h}$, cooled, weighed. Value of neutral detergent fiber, acid detergent fiber, was calculated by equation 4 :

$$
\% \mathrm{NDF} \text { or } \mathrm{ADF}=\underline{(\mathrm{W} 3-(\mathrm{W} 1 \times \mathrm{C} 1)) \times 100}
$$

where: $\mathrm{W} 1$ = empty purse

$\mathrm{W} 2$ = Initial weight of sample

W3 $=$ Weight of sample after extraction process

$\mathrm{C} 1$ = (final dry kiln weight / original blank bag weight $)$.

Non-fibrous carbohydrates (NFC) were calculated using equation 5 adapted from NRC (2001):

$$
\mathrm{NFC} \%=100-(\% \mathrm{NDF}+\% \mathrm{CP}+\% \mathrm{~L}+\% \mathrm{~A}+\mathrm{M})
$$

\subsection{Phytochemical Compounds}

\subsubsection{Evaluation of Flavonoids and Anthocyanins}

In amounts of each bagasse $(0.1 \mathrm{~g})$ a pre-prepared solution $(85: 15)$ of $95 \%$ ethanol $+1.5 \mathrm{~N}$ HCL solution was added. Contents were transferred to glass vials, wrapped in aluminum foil, 


\section{Macrothink

left to stand for 12 hours (overnight) under refrigeration. Material was filtered, read on a digital spectrophotometer (Nova Model $1600 \mathrm{uV}$, Nova Instruments) with a wavelength of 535 nm. Ethanol + HCL solution (85:15) was used as white. Dilution factor was calculated by dividing sample weight $(0.1 \mathrm{~g})$ by dilution volume $(25 \mathrm{~mL})$ (Francis, 1982). Result was correlated with $1 \mathrm{~mL}$ (amount of $\mathrm{g}$ in $1 \mathrm{~mL}$ of solution), determined amount of $\mathrm{mL}$ in $100 \mathrm{~g}$. For flavonoid analysis, same procedure was used with absorbance reading obtained at $374 \mathrm{~nm}$. Equation 6 was used in calculations:

(Absorbance x dilution factor / 98.2)

\subsubsection{Total Tannins}

Total tannins were extracted by dissolving each bagasse $(2.5 \mathrm{~g})$ in distilled water. Mixture was stirred for 30 minutes. An aliquot $(5.0 \mathrm{~mL})$ of filtered mixture was transferred to $100 \mathrm{~mL}$ volumetric flasks. Diluted samples $(0.5 \mathrm{~mL}), 1.0 \mathrm{~mL}$ Folin-Ciocalteau reagent $(1: 10), 2.0 \mathrm{~mL}$ $20 \%$ sodium carbonate were added to test tubes. Tubes were allowed to stand for 30 minutes, protected from light, absorbances were measured on a $760 \mathrm{~nm}$ UV-VIS spectrophotometer. Blank was performed under same conditions using water instead of extracts. Total tannins of extracts were expressed in mg of tannic acid quantified by a tannic acid calibration curve. Calibration curve was constructed in range 0.02 to $1.0 \mathrm{mg} / \mathrm{mL}\left(\mathrm{R}^{2}=0.9972\right)$. All analyzes were performed in triplicate.

\subsection{Statistical Analysis}

Statistical analysis was performed by One-way ANOVA using program STATISTICA ${ }^{\circledR}$ 7.0. All determinations were performed in triplicate $(\mathrm{N}=3)$ and data were expressed as average \pm standard deviation.

\section{Results and Discussion}

\subsection{Composition Chemical and Nutritional}

Dietary fiber is composed of a variety of non-starch polysaccharides that include cellulose, hemicellulose, pectin, $\beta$-glucans and lignin (Figuerola et al., 2005). Chemical composition of fruit ointments is shown in Table 1. There was variation of all constituents: crude protein (0.59-1.67\%), lipids (16.52-0.96\%), mineral residue (6.92-2.36\%), non-fibrous carbohydrate (67.36-28.63\%), neutral detergent fiber $(48.18-18.93 \%)$, acid detergent fiber $(32.28$ $-11.64) \%)$. 


\section{Macrothink}

Table 1. Nutritional composition of fruit pomaces in dry basis (\%)

\begin{tabular}{|c|c|c|c|c|c|}
\hline $\begin{array}{l}\text { Composition } \\
(\%)\end{array}$ & $\begin{array}{l}\text { Citrus } \\
\text { sinensis } \\
\text { (Orange) }\end{array}$ & $\begin{array}{l}\text { Passiflora } \\
\text { edulis } \\
\text { (Passion } \\
\text { fruit) }\end{array}$ & $\begin{array}{c}\text { Punica } \\
\text { granatum } \\
\text { (pomegranate } \\
\text { peel) }\end{array}$ & $\begin{array}{c}\text { Punica } \\
\text { granatum } \\
\text { (Pomegranate } \\
\text { seed) }\end{array}$ & $\begin{array}{c}\text { Vitis } \\
\text { labrusca } \\
\text { (Grape) }\end{array}$ \\
\hline Moisture (U) & $8.31 \pm 0.39$ & $8.12 \pm 0.06$ & $7.73 \pm 0.04$ & $6.37 \pm 0.01$ & $9.47 \pm 0.03$ \\
\hline Lipids (L) & $1.94 \pm 0.08$ & $0.96 \pm 0.03$ & $1.09 \pm 0.04$ & $16.52 \pm 0.09$ & $6.53 \pm 0.41$ \\
\hline $\begin{array}{l}\text { Crude Protein } \\
\text { (CP) }\end{array}$ & $0.88 \pm 0.06$ & $0.59 \pm 0.02$ & $0.86 \pm 0.02$ & $1.67 \pm 0.03$ & $1.26 \pm 0.05$ \\
\hline $\operatorname{Ash}(\mathrm{A})$ & $3.26 \pm 0.06$ & $6.92 \pm 0.03$ & $3.54 \pm 0.16$ & $2.36 \pm 0.07$ & $3.69 \pm 0.04$ \\
\hline $\begin{array}{l}\text { Non-fibrous } \\
\text { carbohydrates } \\
\text { (NFC) }\end{array}$ & $\begin{array}{c}58.37 \pm \\
0.36\end{array}$ & $64.77 \pm 0.08$ & $67.36 \pm 0.05$ & $28.63 \pm 0.14$ & $47.83 \pm 0.39$ \\
\hline $\begin{array}{c}\text { Neutral } \\
\text { Detergent } \\
\text { Fiber (NDF) }\end{array}$ & $\begin{array}{c}18.93 \pm \\
0.44\end{array}$ & $48.18 \pm 0.59$ & $19.42 \pm 0.12$ & $44.45 \pm 1.61$ & $31.22 \pm 1.29$ \\
\hline $\begin{array}{c}\text { Acid } \\
\text { Detergent } \\
\text { Fiber (ADF) }\end{array}$ & $\begin{array}{c}12.46 \pm \\
0.06\end{array}$ & $32.28 \pm 2.52$ & $11.64 \pm 0.09$ & $29.79 \pm 0.89$ & $24.01 \pm 1.12$ \\
\hline
\end{tabular}

* Mean \pm standard deviation of triplicate analyses

According to Van Soest (1994) nutritional fraction of NDF corresponds to sum of hemicellulose, cellulose, lignin. Hemicellulose digestibility is high, cellulose is variable, lignin is an indigestible plant fraction, but composition, structure, content can be affected by plant maturity, environmental factors. Pomaces with higher ADF and lignin content have lower digestibility.

All flours had protein levels below 1.7\%. A healthy adult needs to consume about $0.8 \mathrm{~g}$ protein per kg / weight / day. According to Salinas (2002) it is possible to find 1\% to $3 \%$ protein in vegetables and fruits. This value is little since fruits and vegetables provide small amounts of protein (Philippi, 2008). Passion fruit presented higher mineral content of analyzed poems $(6.92 \%)$. Presence of minerals is very important in disease process. According to Cecchi (2003), high levels of minerals in foods, such as those found in analyzed flours, indicate large amounts of $\mathrm{K}, \mathrm{Na}, \mathrm{Ca}$ and $\mathrm{Mg}$. 
In chemical composition analysis, researchers should be alert to moisture, as a high content of this component may mask content of other constituents. Souza et al. (2008), analyzing centesimal composition of passion fruit flour (Passiflora edulis flavicarpa Degener), found ash levels (8.66 g), lipids (1.75 g), crude protein (12.52 g), total carbohydrates ( $77.07 \mathrm{~g})$, not being analyzed moisture. Carbohydrate exception, all other values of Souza et al. (2008) were superior to those found in this study, although passion fruit species studied were different.

Gontim et al. (2005) examined various poems such as avocado, banana, pineapple, papaya, passion fruit, melon, mandarin and found varying levels of ashes (1.75 to 0.57\%), lipids (11.04-0.55\%), crude protein (0.67-2.49\%), total carbohydrates (2.90-35.64\%). Fiber content was not analyzed in this study. Researchers concluded that, in general, fruit peels have higher levels of nutrients than their edible parts, indicating as an alternative source of nutrients, a fact also shown in this study. Tseng \& Are (2013) in their studies using grape pomace dietary fiber for yogurt and salad enrichment found crude protein $(10.32 \%)$, moisture $(5.63 \%)$, ash $(5.07 \%)$, lipids $(11.09 \%)$, dietary fiber $(61.32 \%)$ in dry matter. Other researchers have incorporated grape pomace and grape seed flour into cereal bars, pancakes and pasta (Rosales Soto et al., 2012) to increase dietary fiber content.

Khosravi et al. (2015) analyzed the nutritional value of pomegranate seeds pulp focusing on crude protein $(6.20 \mathrm{~g} / \mathrm{kg})$, ash $(3.70 \mathrm{~g} / \mathrm{kg})$, neutral detergent fiber $(6.23 \mathrm{~g} / \mathrm{kg})$ analysis, acid detergent fiber $(11.61 \mathrm{~g} / \mathrm{kg}$ ) lipids $(7.54 \mathrm{~g} / \mathrm{kg})$. Ash exception all other values differed from the values found in this study, although several factors may interfere with the results.

Oliveira et al. (2002) when analyzing yellow passion fruit found a fiber content of $4.35 \%$. This fiber content was much lower than that found in this study, since analyzes were performed with different species. Shah et al. (2014) studying chemical composition of bagasse meal of vitis vinifera, Benitaka variety from southern Brazil found a good total of fibers (17 g/100 g). These fiber levels vary depending on influence of genetic variety, weather, humidity, climate and soil.

European Food Safety Authority (EFSA) published, in 2010, a scientific opinion on reference values for carbohydrates and dietary fiber. Role of dietary fiber in intestinal function was considered most appropriate criterion for establishment of adequate intake. Based on evidence available about function of intestine, EFSA considers that intake of $25 \mathrm{~g}$ per day of dietary fiber seems to be suitable for normal defecation in adults, well as adequate for reducing risk of coronary heart disease, type 2 diabetes, improve weight maintenance. Combine use of fruit and vegetable waste with creation of new preparations raises a viable alternative for formulation of products with functional features (Ferreira et al., 2013; Bower; Whitten, 2000).

\subsection{Phytochemical Composition of Pomaces}

Fruit pomates have compounds with important biological properties, such as phenolic compounds (tannins, phenolic acids, anthocyanins), depending on type of residue, cultivar, climate, cultivation conditions (Sousa et al., 2014; Koyama et al. 2007).

Table 2 shows results of quantification of various phytochemical compounds in fruit pomace. All poems contain all compounds analyzed. Pomegranate peel presented higher flavonoid 
contents $(2123.56 \mu \mathrm{g} / 100 \mathrm{~mL})$, tannins. Grapes, higher anthocyanin content $(101.24 \mu \mathrm{g} / 100$ $\mathrm{mL}$ ). In addition to their relevance to plants, flavonoids are important to human health because of their pharmacology activities as radical hijackers (Geleijnse \& Hollman, 2008).

Table 2. Phytochemical compounds in fruit pomace cultivated in semi-arid

\begin{tabular}{lccc}
\hline Samples & $\begin{array}{c}\text { Flavonoids } \\
(\mu \mathrm{g} / 100 \mathrm{~mL})\end{array}$ & $\begin{array}{c}\text { Anthocyanins } \\
(\mu \mathrm{g} / 100 \mathrm{~mL})\end{array}$ & $\begin{array}{c}\text { Tannins } \\
(\mu \mathrm{g} / 100 \mathrm{~mL})\end{array}$ \\
\hline $\begin{array}{l}\text { Punica granatum } \\
\text { (pomegranate peel) }\end{array}$ & $2123.56 \pm 0.22$ & $12.21 \pm 0.02$ & $43.73 \pm 0.27$ \\
$\begin{array}{l}\text { Punica granatum } \\
\text { (Pomegranate seed) }\end{array}$ & $199.21 \pm 0.26$ & $10.21 \pm 0.40$ & $12.93 \pm 0.42$ \\
$\begin{array}{l}\text { Citrus sinensis (Orange) } \\
\text { Passiflora edulis }\end{array}$ & $198.36 \pm 0.36$ & $1.25 \pm 0.04$ & $5.18 \pm 0.08$ \\
(Passion fruit) & $70.09 \pm 0.13$ & $2.08 \pm 0.06$ & $1.55 \pm 0.09$ \\
Vitis labrusca (Grape) & $152.84 \pm 0.19$ & $101.24 \pm 0.32$ & $2.67 \pm 0.04$ \\
\hline
\end{tabular}

* Mean \pm standard deviation of triplicate analyses.

Several authors have investigated citrus fruits and their role in prevention of cardiovascular diseases, have associated these benefits mainly to presence of flavonoids, polyphenol characteristic of citrus species (Khan et al., 2014; Park et al., 2006; Mertz et al., 2009). Anthocyanins belong to group of flavonoids are components of many dark fruits and vegetables, showing great concentration in dark grape skins (Downham \& Collins, 2000). Anthocyanins are included in list of natural compounds capable of acting as potent antioxidants. Its antioxidant potential is regulated by its differences in chemical structure (Galvano et al., 2004), exposure pharmacological properties.

Pomegranate peel presented highest tannin levels among analyzed poems. Tannins are phenolic compounds present in fruits, vegetables that vary in content depending on environmental factors, maturity, harvest time, their presence in high concentrations are associated with astringent characteristics of fruits. These dietary components have beneficial effects on human body, such as antioxidant action, which certainly contributed to a continuous improvement of human health, such as retardation of aging and prevention of certain diseases (Schwager et al., 2008).

\section{Conclusion}

All analyzed pomaces had a varied nutritional profile with varying levels of proteins, lipids, minerals, insoluble fibers, which would justify their use as a food supplement or to enrich foods already consumed by population. Presence of phytochemicals is also an additional incentive for the use of these substances, as anthocyanins, flavonoids and tannins have 
antioxidant potential that makes them healthier in treatment of diseases of inflammatory origin. These findings contribute to desire of population to have functional foods that, in addition to basic nutritional functions, also contribute to treatment of diseases.

\section{Acknowledgments}

Authors are acknowledged to Post-graduate Program in Biotechnology (PPGBIOTEC) at State University of Feira de Santana (UEFS) and at laboratory of food and drinks of SENAI-CIMATEC (BA).

\section{Conflict of Interest}

Authors declare that they have no conflict of interest and this article does not contain any studies with human participants or animals.

\section{References}

AOAC. (1998). Official methods of analysis (16th ed.). Washington, DC: Association of Official Analytical Chemists.

Bower, J. A., \& Whitten, R. (2000). Sensory characteristics and consumer liking for cereal bar snack foods. Journal of Sensorial Studies, 15(3), 327-345.

https://doi.org/10.1111/j.1745-459X.2000.tb00274.x

Cecchi, H. M. (2003). Theoretical and practical foundations in food analysis. 2.ed. Campinas.

Cheung, P. C. K (2013). Mini-review on edible mushrooms as source of dietary fiber: Preparation and health benefits. Food Science and Human Wellness, 2, 162-166.

https://doi.org/10.1016/j.fshw.2013.08.001

Corrêa, R. C., Peralta, R. M., Haminiuk, C. W., Maciel, G. M., Bracht, A., \& Ferreira, I. C. (2016). The past decade findings related with nutritional composition, bioactive molecules and biotechnological applications of Passiflora spp.(passion fruit). Trends in food science \& technology, 58, 79-95. https://doi.org/10.1016/j.tifs.2016.10.006

Downham, A., \& Collins, P. (2000). Colouring our foods in the last and next millennium. International Journal of Food Sciences Technology, 35(1), 5-22.

https://doi.org/10.1046/j.1365-2621.2000.00373.x

EFSA (2010). Scientific opinion on dietary reference values for carbohydrates and dietary fibre. European Food Safety Authority (EFSA) Journal, 8(3), 1462.

https://doi.org/10.2903/j.efsa.2010.1462

Elleuch, M., Bedigian, D., Roiseux, O., Besbes, S., Blecker, C., \& Attia, H. (2011). Dietary fibre and fibre-rich by-products of food processing: characterisation, technological functionality and commercial applications: a review. Food Chemistry, 124, 411-421. https://doi.org/10.1016/j.foodchem.2010.06.077

Ferreira, M. S. L., Santos, M. C. P., Moro, T. M. A., Basto, G. J., Andrade, R. M. S., \& Gonçalves, E. C. B. A. (2013). Formulation and characterization of functional foods based on 
fruit and vegetable residue flour. Journal of Food Science and Technology, 52(2), 822-830. https://doi.10.1007/s13197-013-1061-4.

Figuerola, F., Hurtado, M. L., Estevez, A. M., Chiffelle, I., \& Asenjo, F. (2005). Fibre concentrates from apple pomace and citrus peel as potential fibre sources for food enrichment. Food Chemistry, 91, 395-401. https://doi.org/10.1016/j.foodchem.2004.04.036

Francis, F. J. (1982). Analysis of anthocyanins. In: Markakis P. (ed.) Anthocyanins as Food Colors. New York: Academic Press, 182-205.

Galvano, F., La Fauci, L., Lazzarino, G., Fogliano, V., Ritieni, A., Ciappellano, S., ... \& Galvano, G. (2004). Cyanidins: metabolism and biological properties. The Journal of Nutritional Biochemistry, 15(1), 2-11. https://doi.org/10.1016/j.jnutbio.2003.07.004

Geleijnse, J. M., \& Hollman, P. (2008). Flavonoids and cardiovascular health: which compounds, what mechanisms? The American Journal of Clinical Nutrition, 88(1), 12-13. https://doi.org/10.1093/ajcn/88.1.12

Gondim, J. A. M., Moura, M. F. V., Dantas, A. S., Medeiros, R. L. S., \& Santos, K. M. (2005). Centesimal composition and minerals in fruit peels. Food science and technology, 25(4), 825-827. http://dx.doi.org/10.1590/S0101-20612005000400032

Kaczmarczyk, M. M., Miller, M. J., \& Freund, G. G. (2012). The health benefits of dietary fiber: Beyond the usual suspects of type 2 diabetes mellitus, cardiovascular disease and colon cancer-review. Metabolism Clinical and Experimental, 61, 1058-1066.

https://doi.org/10.1016/j.metabol.2012.01.017

Khan, M. K., Zill, E. H., \& Dangles, O. (2014). A comprehensive review on flavanones, the major citrus polyphenols. Journal Food Composition Analitical, 33, 85-104.

https://doi.org/10.1016/j.jfca.2013.11.004

Khosravi, F., Fathi Nasri, M. H., Farhangfar, H., \& Modaresi, J. (2015). Nutritive value and polyphenol content of pomegranate seed pulp ensiled with different tannin-inactivating agentes. Animal Feed Science and Technology, 207, 262-266.

https://dx.doi.org/10.1016/j.anifeedsci.2015.06.004

Kim, M. J., Moon, Y., Kopsell, D. A., Park, S., Tou, J. C., \& Waterland, N. L. (2016). Nutritional value of crisphead 'Iceberg'and romaine lettuces (Lactuca sativa L.). J. Agric. Sci, 8, 734. https://doi.org/10.5539/jas.v8n11p1

Koyama, K., Goto-Yamamoto, N., \& Hashizume, K. (2007). Influence of maceration temperature in red wine vinification on extraction of phenolics from berry skins and seeds of grape (Vitis vinifera). Biosciences Biotechnology Biochemistry, 71, 958-965. https://doi.org/10.1271/bbb.60628

Ktenioudaki, A., \& Gallagher, E. (2012). Recent advances in the development of high fibre baked products. Trends Food Science Technology, 28, 4-14.

https://doi.org/10.1016/j.tifs.2012.06.004 
Mertz, C., Gancel, A. L., Gunata, Z., Alter, P., Dhuique-Mayer, C., Vaillant, F., ... \& Brat, P. (2009). Phenolic compounds, carotenoids and antioxidant activity of three tropical fruits. Journal of Food Composition and Analysis, 22(5), 381-387.

https://doi.org/10.1016/j.jfca.2008.06.008

Mirabella, N., Castellani, V., \& Sala, S. (2014). Current options for the valorization of food manufacturing waste: A review. Journal of Cleaner Production, 65, 28-41.

https://doi.org/10.1016/j.jclepro.2013.10.051

Mudgil, D., \& Barak, S. (2013). Composition, properties and health benefits of indigestible. carbohydrate polymers as dietary fiber: A review. International Journal of Biological Macromolecules, 61, 1-6. https://doi.org/10.1016/j.ijbiomac.2013.06.044

Oliveira, L. F. D., Nascimento, M. R. F., Borges, S. V., Ribeiro, P. C. D. N., \& Ruback, V. R. (2002). Aproveitamento alternativo da casca do maracujá-amarelo (Passiflora edulis F. Flavicarpa) para produção de doce em calda. Sociedade Brasileira de Ciência e Tecnologia de Alimentos, 22(3), 259-262. http://dx.doi.org/10.1590/S0100-29452004000100027

Papathanasopoulos, A., \& Camilleri, M. (2010). Dietary fiber supplements: effects in obesity and metabolic syndrome and relationship to gastrointestinal functions. Gastroenterology, 138, 65-72. https://doi.org/10.1053/j.gastro.2009.11.045

Park, Y. S., Cvikrová, M., Martincová, O., Ham, K. S., Kang, S. G., Park, Y. K., ... \& Gorinstein, S. (2015). In vitro antioxidative and binding properties of phenolics in traditional, citrus and exotic fruits. Food Research International, 74, 37-47.

https://doi.org/10.1016/j.foodres.2015.04.021.

Philippi, S. T., Latterza, A. R., Cruz, A. T. R., \& Ribeiro, L. C. (1999). Adapted food pyramid: a guide for a right food choice. Journal of nutrition, 12(1), 65-80.

http://dx.doi.org/10.1590/S1415-52731999000100006

Rodriguez-Casado, A. (2016). The health potential of fruits and vegetables phytochemicals: Notable examples. Critical Reviews in Food Science and Nutrition, 56(7), 1097-1107. https://doi.org/ 10.1080/10408398.2012.755149

Rosales Soto, M. U., Brown, K., \& Ross, C. F. (2012). Antioxidant activity and consumer acceptance of grape seed flour-containing food products. International Journal of Food Science \& Technology, 47(3), 592-602. https://doi.org/10.1111/j.1365-2621.2011.02882.x

Salinas, R. D. (2002). Food and Nutrition: introduction to food science. In Food and vegetables. 3ed.PortoAlegre: Artmed, p. 164-181. (in portuguese)

Schwager, J., Mohageri, M. H., Fowler, A., \& Weber, P. (2008). Challenges in discovering bioactives for the food industry. Current Opin in Biotechology, 19, 66-72.

https://doi.org/10.1016/j.copbio.2008.02.016

Shah, M. A., Bosco, S. J. D., \& Mir, A. A. (2014). Plant extracts as natural antioxidants in meat and meat products. Meat Science, 98, 21-23.

https://doi.org/10.1016/j.meatsci.2014.03.020 
Sheng, K., Shui, S., Yan, L., Yu, J., Hao, G., Qu, H., ... \& Zheng, L. (2018). The beneficial effects of dietary grape supplementation on improving cognitive deficits in APP/PS1 double transgenic mice. Journal of functional foods, 49, 224-234.

https://doi.org/10.1016/j.jff.2018.08.030

Solà, R., Bruckert, E., Valls, R.M., Narejos, S., Luque, X., Castro-Cabezas, M., ... \& Anguera, A. (2010). Soluble fibre (Plantago ovata husk) reduces plasma low-density lipoprotein (LDL) cholesterol, triglycerides, insulin, oxidised LDL and systolic blood pressure in hypercholesterolaemic patients: a randomised trial. Atherosclerosis, 211(2), 630-637. https://doi.org/10.1016/j.atherosclerosis.2010.03.010

Sousa, E. S., Uchôa-Thomaz, A. M. A., Carioca, O. B., Morais, S. M., Lima, A., Martins, C. G., ... \& Rodrigues, L. L. (2014). Chemical composition and bioactive compounds of grape pomace (Vitis vinifera L.), Benitaka variety, grown in the semiarid region of Northeast Brazil. Food Science Technology, 34(1). http://dx.doi.org/10.1590/S0101-20612014000100020

Souza M. W. S., Ferreira, T. B. O., \& Vieira, I. F. R. (2008). Centesimal composition and technological functional properties of flour peeling Passion fruit. Food and Nutrition, 19(1). (in portuguese). http://dx.doi.org/10.1590/0103-8478cr20131437

Tseng, A., \& Zhao, Y. (2013). Wine grape pomace as antioxidant dietary fibre for enhancing nutritional value and improving storability of yogurt and salad dressing. Food Chemistry, 138, 356-365. https://doi.org/10.1016/j.foodchem.2012.09.148

Van Soest, P. J. (1994). Nutritional ecology of the ruminant. Ithaca: Comstock Publ. Assoc.

Yan, L., Li, T., Liu, C., \& Zheng, L. (2019). Effects of high hydrostatic pressure and superfine grinding treatment on physicochemical/functional properties of pear pomace and chemical composition of its soluble dietary fibre. $L W T, 107,171-177$.

https://doi.org/10.1016/j.lwt.2019.03.019

Zhang, R., Han, S., Zhang, Z., Zhang, W., Yang, J., Wan, Z., \& Qin, L. (2018). Cereal Fiber Ameliorates High-Fat/Cholesterol-Diet-Induced Atherosclerosis by Modulating the NLRP3 Inflammasome Pathway in ApoE-/-Mice. Journal of agricultural and food chemistry, 66(19), 4827-4834. https://doi.org/10.1021/acs.jafc.8b00380

Zhao, C. N., Meng, X., Li, Y., Li, S., Liu, Q., Tang, G. Y., \& Li, H. B. (2017). Fruits for prevention and treatment of cardiovascular diseases. Nutrients, 9, 598.

https://doi.org/10.3390/nu9060598

\section{Copyright Disclaimer}

Copyright for this article is retained by the author(s), with first publication rights granted to the journal.

This is an open-access article distributed under the terms and conditions of the Creative Commons Attribution license (http://creativecommons.org/licenses/by/4.0/). 